Equal in His Sight: An Examination of the Evolving Opinions on Race in the Life of Jerry Falwell, Sr.

\title{
Kathryn Legg
}

A Senior Thesis submitted in partial fulfillment of the requirements for graduation in the Honors Program Liberty University

Fall 2019 
Acceptance of Senior Honors Thesis

This Senior Honors Thesis is accepted in partial fulfillment of the requirements for graduation from the Honors Program of Liberty University.

Robert A. Robertson, J.D.

Thesis Chair

Kahlib Fischer, Ph.D.

Committee Member

David Schweitzer, Ph.D.

Assistant Honors Director

Date 


\begin{abstract}
The late Reverend Jerry Falwell, Sr., founder of Thomas Road Baptist Church and president of the Moral Majority, was a prominent figure in conservative politics beginning in the late 1970s. His opinions regarding preachers and politics changed throughout his life, as did his beliefs about race in America and the church. His views on race affected his preaching and political involvement, and in his later life he retracted from the segregationist beliefs he held at the beginning of his ministry. While Falwell's prominent roles in the Religious Right and Moral Majority have previously been explored, this paper seeks to present a concentrated look at Falwell's evolving opinions regarding race.
\end{abstract}


Equal in His Sight: An Examination of the Evolving Opinions on Race in the Life of Jerry Falwell, Sr.

\section{Introduction}

The intersection of religion and race relations in American history is storied and complex. It reaches back to the beginning of European conquest in the western world and Christopher Columbus's vision for converting the native people he encountered when he first landed in the Americas (Delaney, 2006). The meeting of race and religion has not always been positive; for hundreds of years the institution of slavery was defended in pulpits with misinterpreted Bible verses. Others preached the equality of all people and became ardent abolitionists and advocates for civil rights.

Throughout the history of America, many have found themselves in positions of prominence pertaining to the meeting of religion and race. One such individual was the late Reverend Jerry Falwell, Sr., founder and pastor of Thomas Road Baptist Church in Lynchburg, Virginia. He also was a co-founder of Liberty University and of the Moral Majority, an organization that helped build a conservative voting bloc in the 1980 s. His opinions, specifically regarding race and politics, transformed throughout his decadeslong ministry, and he himself admitted changes of heart that occurred in his life. His evolving beliefs were affected by national movements, personal interactions, and the influence of God in his life, and he in turn used his position of prominence to speak loudly about religious and political matters in America. 


\section{Lynchburg History and Falwell's Upbringing}

Prior to the Civil War, Lynchburg's population consisted of 42 percent slaves, and 40 percent of the white population owned or hired at least one slave ("Redlining in Lynchburg," 2019). After the war, business shifted to mills and factories, which were segregated. During the 1930s and 40s, Lynchburg, like most cities in America, was heavily affected by the Great Depression and Second World War (FitzGerald, 1981). Property zoning laws were used to help preserve white property values, confining most black families to the urban core of Lynchburg. During the Depression, the black unemployment rate was almost 50 percent ("Redlining in Lynchburg," 2019).

In the 1950s, national companies such as Babcock \& Wilcox and General Electric came to Lynchburg, drawn by the low property taxes and relatively cheap labor (Williams, 2010b). By 1980, the town was home to over 200 factories (Williams, 2010a), which helped bring money and stability to Lynchburg. The city was mostly segregated until the 1960s when the civil rights movement pressured companies to hire black workers (FitzGerald, 1981). Additionally, the prospect of schools closing due to Virginia's Massive Resistance policy pushed managers to support integration efforts; school closings would be bad for business (Williams, 2010a). Politically, the northernborn factory managers brought new life to the city's Republican party. While the plant workers were more likely to be Democrat, they agreed with their managers' anticommunist beliefs (Williams, 2010a).

Jerry Lamon Falwell, Sr., was born on August 11, 1933, in Lynchburg, Virginia, to parents Carey and Helen Falwell. His father owned several businesses throughout the 
city, and his mother stayed at home to take care of Falwell and his three siblings. Falwell was undoubtedly influenced by the history of racism and discrimination in his own family and in Lynchburg, and he talked openly about the segregationist environment in which he was raised. In his book Falwell: An Autobiography, Falwell (1997) says that he and his twin brother Gene spent much of their childhood playing with the black children whose parents worked for their father Carey in his various businesses. Gene said that their grandfather used to make fun of the "colored boys" who worked for Carey (FitzGerald, 1981, para. 55). In an interview for a book in 1984, Falwell stated, "Blacks were not known as Blacks in our area. They were known as Niggers. This was common conversation" (Simon, 1984, p. 6). He stated that it was difficult for a boy to grow up in that environment and not digest the beliefs and rhetoric into his own attitude and vocabulary; Falwell added that he did not know anyone who was not a segregationist but that he eventually reached a point in his life where he "loved all persons in the same way God loves all persons” (Simon, 1984, p. 151).

Falwell described his father as a strict segregationist when it came to business but that “there wasn't a black man or woman who knew him that didn't consider him their friend" (Falwell, 1997, p. 61). He testified to having "plenty" of black friends and acquaintances, adding that though segregation was "in place to keep us apart, from my earliest years I loved and was loved by black friends, neighbors, and employees of my family" (Falwell, 1997, p. 301). He also talked at length and spoke highly of David Brown, a black man who took care of Falwell and his siblings during their childhood (Falwell, 1997, p. 58, 301-302). 


\section{Falwell's Education and Founding of TRBC}

\section{Baptist Bible College}

After graduating high school, Falwell enrolled in pre-mechanical engineering classes at Lynchburg College. He accepted Jesus Christ as his Savior at age 18, after

which he decided to attend Baptist Bible College in Springfield, Missouri (Sutton, 2013), a college founded by the staunchly anti-communist Baptist Bible Fellowship (Williams, 2010b). There he sat under the teaching of fundamentalist preachers such as G.B. Vick and Noel Smith, both of whom were unwavering segregationists (Lavoie, 2013).

Falwell said that race issues first began to become real to him in 1954 when the Supreme Court declared in Brown v. Board of Education of Topeka that the separate but equal doctrine was unconstitutional. Later, when Rosa Parks refused to give her seat on a city bus to a white man, Falwell said he initially felt the national controversy that ensued seemed "silly and overblown" (Falwell, 1997, p. 302). He said that Southerners did not understand how much black people had suffered. Falwell continued, "When Rosa Parks refused to budge, she launched a second American revolution; but I was too young and too excited about my newfound Christian faith to realize that one day the revolution would come to my door and change my life and ministry forever" (Falwell, 1997, p. 302303). He felt that he and his Southern friends did not initially feel the injustice of segregation but later they began to feel uneasy about the separate but equal doctrine that was ingrained into the culture of the South. 


\section{Thomas Road Baptist Church}

After graduating from Baptist Bible College, Falwell moved back to Lynchburg and helped found Thomas Road Baptist Church (TRBC). Almost immediately after he became pastor, he began knocking on doors in the community to invite people to church. He also bought airtime to broadcast sermons, following in the footsteps of the Old Fashioned Revival Hour and evangelist Bob Jones, who he had grown up listening to on the radio (Sutton, 2013).

The church was comprised primarily of those in lower and middle class income brackets, including some who were on government assistance. Many of the early

members were working class and had little formal education (Williams, 2010b). Most, if not all, of the congregation was white. Falwell's outreach ministry targeted lower-class whites, not as a "conscious decision to limit his preaching to blue-collar workers but because those were the people he knew best" (Williams, 2010b, para. 10). If there were any black attendees, they could not become members until 1968 (E. Towns, personal communication, January 22, 2019; Martin, 1996; Williams, 2010b). However, Falwell said in his autobiography that black people could attend TRBC from the beginning, but "they would not think to join and we would not think to ask them" (Falwell, 1997, p. $303)$.

According to Falwell in a later interview, he baptized the first black family at TRBC in 1960 or '61 (Martin, 1996). He said that an interaction with an elderly black man named Lewis in 1963 who shined his shoes each week opened his eyes to the 
possibility of black people in his congregation (Falwell, 1997). Falwell acknowledged

that several families left TRBC over the issue. However, there is some dispute over dates: it does not appear that the first black family became members at TRBC until $1968,{ }^{1}$ and the first baptism of a black member, which was done by Dr. Elmer Towns, did not occur until 1971 (E. Towns, personal communication, January 22, 2019; Martin, 1996). Falwell attests to the later date in both of his autobiographies, saying that the first black family applied for membership shortly after the assassination of Martin Luther King, Jr., in 1968 (Falwell, 1987; Falwell, 1997).

In an article for The New Yorker magazine in 1981, a reporter asked TRBC pastors about the church's attempts to evangelize Lynchburg's black population. The pastors said they didn't make much of an effort to reach black people in the city. When Falwell was asked the same question, he said that black pastors would resent TRBC's outreach and "leading people" away from their churches (FitzGerald, 1981, para. 132). Reverend Jim Moon, who was co-pastor at TRBC for several decades, answered slightly differently, saying, "I don't think the white man will ever reach the black population. They don't trust us and never will. We have to train black pastors to reach them. We are a white church and will always be that way" (FitzGerald, 1981, para. 132).

The ministers of some of the larger churches at the time, where many Lynchburg elite from both the North and the South gathered, took anti-segregation stances. For example, the pastor of Lynchburg's United Church of Christ publically supported

\footnotetext{
${ }^{1}$ Dr. A. Pierre Guillermin, who did not move to Lynchburg until 1967, also recalled the first black family joining TRBC earlier than 1968 (A.P. Guillermin, personal communication, January 30, 2019).
} 
integration; the church also hosted Martin Luther King, Jr. (MLK), at its interracial coffee shop. "The mainline Protestant ministers viewed Falwell as a reactionary whose time had passed" (Williams, 2010b, para. 16). One pastor was quoted as saying that Falwell was “just another segregationist preacher” (Williams, 2010b, para. 16).

Besides the sermons Falwell preached on segregation, he was also the chaplain of the Lynchburg chapter of the Defenders of State Sovereignty and Individual Liberty, which was a state organization that supported segregation and the Massive Resistance policy. Falwell led the closing prayer for the organization's first mass meeting, and the speaker for the event would later head the ticket for Virginia's pro-segregationist Conservative Party (Williams, 2010b). In the early 1960s, Falwell helped distribute antiMartin Luther King, Jr., literature furnished by FBI Director J. Edgar Hoover (Martin, 1996).

\section{Falwell Sermons and Segregation in Lynchburg}

\section{"Segregation or Integration: Which?"}

In 1958, four years after the groundbreaking Supreme Court decision in Brown $v$. Board of Education of Topeka, Falwell preached a sermon at TRBC entitled "Segregation or Integration: Which?" He stated that chaos resulted from the Brown ruling and that "there is more racial tension than has been in the history of the negro's stay in America" (Word of Life, 1958, p. 1). His argument relied on two traditional objections to integration, "the Hamitic Curse and an eschatological view of Communism" (Lavoie, 2013, p. 82). This view was taught by the Baptist Bible Fellowship, which was the overarching organization of Baptist Bible College (Lavoie, 2013). Falwell continued in 
the sermon, "We have left God out of decisions altogether. If Chief Justice Warren and his associates had known God's Word and had desired to do the Lord's will, I am quite confident that the 1954 decision would never have been made" (Word of Life, 1958, p. $1)$.

Throughout the rest of the sermon, Falwell cited Bible passages, including Deuteronomy 32:8 and Genesis 9:18-27, that he argued proved the God-ordained segregation of races. While he said that "the soul of the negro is just as valuable in the sight of God as the soul of the white man" (Word of Life, 1958, p. 1), he also added that "when God has drawn a line of distinction, we should not attempt to cross that line" (Word of Life, 1958, p. 1). He viewed segregation as respecting God's law, not as an offense to a person's humanity. He blamed white men for the problem of segregation altogether, saying that the issue would not exist if they had not brought black men and women to the United States as slaves from Africa (Word of Life, 1958).

Falwell continued:

If we persist in tearing down God's barriers, God must punish us for it. The theory of communism is social equality—but there is no such thing. Souls are of equal value and importance, but that is as far as we can go. The true negro does not want integration. He realizes his potential is far better among his own race. Who then is propagating this terrible thing?... Finally, we see the Devil himself behind it. What will integration of the races do to us? It will destroy our race eventually (Word of Life, 1958, p. 4). 
Falwell said that the ultimate tragedy to occur as a result of school integration would be marriages between races. He finished the sermon by saying that with prayer the Supreme Court's opinion could be changed and that "it is so easy to let the flesh dominate us, but if we live in constant fellowship with the Lord, He can enable to live a Christ-like life before others" (Word of Life, 1958, p. 4).

"Ministers and Marches"

Seven years later, Falwell preached another sermon addressing the civil rights movement. Titled "Ministers and Marches," the message was later distributed as a pamphlet across the country. Falwell delivered the message on March 21, 1965. This was also around the same time that the Selma-Montgomery marches were taking place, led in part by Dr. Martin Luther King, Jr. (“Selma to Montgomery March,” n.d.).

Falwell began by saying that every American had the right to peacefully petition for redress of grievances. The central question of Falwell's sermon was whether the church had a command from God to involve itself in "marches, demonstrations, or any other actions, such as many ministers and church leaders are so doing today in the name of civil rights reforms" (Thomas Road Baptist Church, 1965, p. 1). Falwell continued, saying, "I do question the sincerity and non-violent intentions of some civil rights leaders such as Dr. Martin Luther King, Jr., Mr. James Farmer, and others, who are known to have left-wing associations" (Thomas Road Baptist Church, 1965, p. 2). He repeated what he had contended in his earlier "Segregation or Integration: Which?" sermon: Communists were using national unrest to infiltrate their ideology into American society. Falwell reiterated, "But I must repeat that I do believe many sincere persons are 
participating. I must also say that I believe these demonstrations and marches have done more to damage race relations and to gender hate than to help" (Thomas Road Baptist Church, 1965, p. 2).

Throughout the rest of the sermon, Falwell focused on the gospel being central for positive social change to occur. His message was that the Great Commission is the Christian's greatest command. Falwell said, "Nowhere are we commissioned to reform the externals. We are not told to wage wars against bootleggers, liquor stores, gamblers, murderers, prostitutes, racketeers, prejudiced persons or institutions, or any other existing evil as such. Our ministry is not reformation but transformation" (Thomas Road Baptist Church, 1965, p. 3).

Falwell also discussed the Christian's citizenship in heaven. He emphasized the temporary nature of human citizenship on earth and said that the highest purpose for a person is to "know Christ and to make Him known" (Thomas Road Baptist Church, 1965, p. 7). He said, "Believing the Bible as I do, I would find it impossible to stop preaching the pure saving gospel of Jesus Christ, and begin doing anything else-including fighting communism, or participating in civil rights reforms. As a God-called preacher, I find that there is no time left after I give the proper time and attention to winning people to Christ. Preachers are not called to be politicians but to be soul winners" (Thomas Road Baptist Church, 1965, p. 7). He bolstered his argument by citing Jesus' words from Matthew 22:15-22 regarding paying taxes to Caesar. Falwell concluded, "In other words, [Jesus] said, 'Pay your taxes, forget politics, and serve Me with all your heart'” (Thomas Road Baptist Church, 1965, p. 7). 
Later he discussed the story of the woman at the well in John 4:6-13. The woman was a Samaritan, a group of people who were generally despised by the Jews. When Jesus encountered her at a well in the desert, he asked her to draw him a drink of water with the bucket she had. The woman asked why Jesus, a Jew, would ask her, a Samaritan woman, for a drink. Falwell commented,

This woman was saying to Jesus that the Jews were segregated from the Samaritans. It was much like many of the situations existing today in America and in other countries between different nations and races. But as we read the rest of the account, we see that Jesus totally ignored her attempt to involve Him in a discussion about segregation. He immediately began to tell her that her need was spiritual water (Thomas Road Baptist Church, 1965, p. 10).

Falwell concluded, "When she became a Christian, she forgot all about any racial differences" (Thomas Road Baptist Church, 1965, p. 10-11). This appears to be a change in Falwell's opinion from 1958, when he identified racial differences to be so significant that God intended people with different skin colors to inhabit different areas of the world, to attend different churches, and to live in different neighborhoods.

Falwell questioned if the reason for the "so-called freedom movement" was because black people in America presented a strong voting bloc in the future, stronger than the American Indian population he suggested (Thomas Road Baptist Church, 1965, p. 14). He questioned why the church should be involved in social reforms like civil rights if it was not concerned about the alcoholism problem in America. Falwell said, "There are almost as many alcoholics as there are negroes" (Thomas Road Baptist 
Church, 1965, p. 14). He concluded by saying that discrimination is present in every place in some form or another but that, "As Christians, we detest discrimination" (Thomas Road Baptist Church, 1965, p. 16).

Falwell recalled all copies of his earlier sermons sometime around 1970. "Ministers and Marches," which was distributed as a pamphlet after Falwell preached it at a TRBC Sunday night service, ${ }^{2}$ is among the few sermons to survive the recall (Harding, 2000). Falwell's orders are evident in a note on a "Ministers and Marches" pamphlet that was sent back to him, which reads, "My Aunt in Atlanta says Jerry would like to buy this back. But here's one free. ha! ha! A friend of Bob Jones from Greenville sent me this!' (Harding, 2000, p. 286).

Falwell publically denounced his "Ministers and Marches" sermon in 1980, calling it "false prophecy" (Harding, 2000, p. 26; Ray, 1985, p. 28). In 1995 Falwell reflected on his 1965 sermon and said,

I was saying to pastors that we should not be involved politically; we should not be out leading marches, we should not be out demonstrating, doing lie-ins, and pray-ins and sleep-ins and so forth. We should be preaching the gospel and changing people's hearts. And I used my own testimony in that sermon about how, in the early days, we had refused to accept black members in our church and how, when I came to the conviction of the wrongness of that position and baptized the first black family here, we had lost people over it. ${ }^{3}$ But I still had the

\footnotetext{
${ }^{2}$ Portions of the sermon were also published in the Sunday, March 29, 1965, edition of The News in Lynchburg.

${ }^{3}$ The first black family was not welcomed at TRBC until 1968, three years after the "Ministers and Marches" sermon.
} 
confidence then that government, the courts, the Congress, would correct these social ills; I had the confidence that we could trust government to make the difference. I was wrong, and later, of course, became very involved (Martin, 1996, p. 70).

\section{Liberty Christian Academy and Liberty University}

\section{Educational Environment in Virginia}

Public schools, colleges, and universities in Virginia were segregated since they were first instituted in 1870. The National Association for the Advancement of Colored People (NAACP) began to challenge these laws in the 1930s and won a victory for equal pay for black teachers in 1940. The Virginia state NAACP joined its national branch in bringing the lawsuit Davis et al. v. County School Board of Prince Edward County, Virginia in 1951 to fight the constitutionality of segregation. That case was ruled on in combination with other similar cases in Brown v. Board of Education of Topeka. The 1954 decision declared segregation to be unconstitutional, and in a 1955 ruling, often referenced as Brown II, declared that desegregation in schools was to be implemented "with all deliberate speed," but no specific deadline was set (Daugherity, 2014, para. 6).

Many in the South opposed desegregation and fought the implementation of the Supreme Court's ruling in Brown. White resistance was encouraged by white segregationist organizations, and Virginia state officials fought the Brown decision in court cases and by passing legislation that made implementing desegregation more difficult under a policy known as Massive Resistance. Through state laws and other restrictive policies, fewer than 12,000 of the approximately 235,000 black students in 
Virginia went to desegregated schools as of 1965 (Daugherity, 2014). However, not all in the state supported Massive Resistance; white moderates in the Senate and federal judges found the Resistance laws too defiant and ordered the implementation of desegregation in public schools (Thomas, 2005). Private schools were not held to the Brown ruling.

The federal government used portions of the Civil Rights Act of 1964 to threaten the loss of federal funding if schools did not integrate. Additionally, the Supreme Court cases such as Charles C. Green et al. v. County School Board of New Kent County, Virginia, et al. and Swann v. Charlotte-Mecklenburg, North Carolina helped accelerate the process of integration of schools in the south. By the mid-1970s, schools throughout the nation were desegregated (Daugherity, 2014).

Lynchburg began removing segregation policies in the 1960s due to pressures stemming from the Civil Rights movement. The last holdout for segregated facilities in Lynchburg was Guggenheimer Memorial Hospital in 1966 (Guggenheimer lifts ban on integration, 1966). Lynchburg city schools first began to be integrated in 1961, but were all integrated by 1967 (Laurant, 2012). These policies and movements set the stage for the founding of Lynchburg Christian Academy in fall 1967.

\section{Lynchburg Christian Academy}

In 1967 TRBC opened Lynchburg Christian Academy (LCA), later known as Liberty Christian Academy. The school was first announced on November 10, 1966 (Brooks, 1966). Falwell recruited Dr. A. Pierre Guillermin, then the president of a small Methodist college in South Carolina, to help him build and run the school (Menard, 2012). Guillermin stated that he agreed to come to Lynchburg only if Falwell intended to 
build a university in addition to an elementary and high school. Falwell assented to the idea of a Liberty educational system, and Guillermin moved to Lynchburg to assume the role of LCA's first administrator (A.P. Guillermin, personal communication, January 30, 2019).

Falwell was quoted in the November $10^{\text {th }}$ article as saying that the school would be non-sectarian and non-denominational. He refused to answer whether the school would be integrated or not, saying that he was not at liberty to say since the school board had not been entirely determined. He also said that the school would receive no federal funds (Brooks, 1966). On December 1, 1966, LCA's school board members were announced. An article from The News published the following day reported that the school would admit whites only ("Board Members Named," 1966).

In April 1967 the Lynchburg Ministerial Association, a group of ministers of various denominations in Lynchburg, decried the use of the word Christian with the school Falwell and his associates intended to start because the school had a white-only policy ("Teaching religion proposed," 1967). In his autobiography, Falwell states that he did not deny that the school was white only because no such policy existed. He said, "When Dr. Pierre Guillermin and I discussed the possibility of starting Christian Schools in Lynchburg, the idea of circumventing integration was never discussed. And though we had only white students apply during our first two years, in 1969 we took in our first black child without fanfare and have been integrated in every grade up until this day" (Falwell, 1997, p. 321). 
According to Dr. Elmer Towns (personal communication, January 22, 2019), a co-founder of Liberty University, "certain things" happening in Virginia at the time of LCA's founding were the cause for the school being white-only for its first two years. He mentioned Prince Edward County's closing of all its schools rather than integrating. Towns said, "In this area, there was a real issue around here. Jerry had that issue in him. He had been saved, so he looked at the world through the eyes of the Great Commission." Guillermin (personal communication, January 30, 2019) stated that he did not recall a white-only policy at LCA, nor did he remember "anyone from any other race [trying] to enroll.” He said, "And [integration] was not a problem. It would've been perfectly acceptable to us." He blamed public perception for rumors of a white-only policy. Guillermin continued, "There was no policy at all. In fact, it was never discussed. I cannot remember a time when Dr. Falwell even mentioned the possibility of restricting enrollment." He said that members of TRBC may have been motivated by the school integration in Lynchburg to send their kids to LCA but that it was not really discussed. Guillermin's statement about there being no discussion of LCA being segregated appears to be at odds with the November 10, 1966, News and Advance article in which Falwell was explicitly asked if the school would be white-only. In his autobiography, Falwell said that he never denied the white-only policy because there wasn't one (Falwell, 1997), but on other occasions he said that the newspaper made a mistake in labeling LCA as "whites only" (Martin, 1996, p. 71).

Regarding the purpose of the school, Falwell's purpose for founding LCA centered around providing quality training in Christian living and academics, especially 
given the lack of Bible reading and prayer in public school ("Board members named for private school," 1966). An August 1967 Impact pamphlet distributed by LCA echoes Falwell's comments about the purpose of the school, comparing the goals of secular and Christian education and emphasizing the need for teaching about "ultimate purpose" in schools, namely, glorifying God (Lynchburg Christian Academy, 1967). There were other private schools in the Lynchburg area, but none that were trying to provide a Christian-based education (A.P. Guillermin, personal communication, January 30, 2019). While LCA admitted only white students for the first two years, it does not appear to have had a written segregation policy (Falwell, 1978; Falwell, 1997).

\section{Liberty University}

Liberty University, originally Lynchburg Baptist College, was founded in 1971. Towns (personal communication, January 22, 2019) said that he and Falwell envisioned the school being built on three pillars: academic excellence, up-to-date communication, and being local church ministry-focused. Falwell said that he did not want the school to be like Bob Jones University (BJU) because of the school's legalism. Falwell was concerned that some at TRBC would not be ready for a fully integrated college, and Towns told him that he was committed to starting a fully integrated college from its inception. Towns said,

Liberty has always bent over backwards to give scholarships to African Americans because of the Great Commission. "Red and yellow, black and white, they are equal in his sight." That's the motive. The motive is not to keep the law. 
The motive is not to be politically correct. The motive is to please God (E. Towns, personal communication, January 22, 2019).

LU accepted one black student its first year. The school's policy on interracial dating at the time was that it was not allowed unless the students' parents gave their permission. Towns said (personal communication, January 22, 2019), "Liberty would not give permission for that. It should be between the students and their parents, and not with us." It was viewed as a family matter rather than a university issue.

That same year, Towns baptized a black, 22-year-old Air Force-signee at TRBC to signify the inclusion of black members in the church. The man wanted to become a member and have support from his church when he returned from service. The baptism was the first of a non-white member at TRBC (E. Towns, personal communication, January 22, 2019).

\section{Falwell's Changing Beliefs}

Falwell's beliefs on race and religion changed from the time he first began preaching to the end of his life. Towns (personal communication, January 22, 2019) believes that Falwell began to realize he was wrong around 1968 when TRBC's bus ministry started. Children of all races began to come to TRBC and soon brought their families with them. Towns said, "When he saw that we could reach them for Christ, and they come to church and want to be saved-I think that changed him."

\section{Apologies}

Towns (personal communication, January 22, 2019) said that Falwell apologized for his wrong beliefs in 1979 at Court Street Baptist Church in Lynchburg. Reverend 
Jesse Jackson was speaking at the church, and Falwell went to hear him speak. Jackson and Falwell met before Jackson spoke, and he agreed to give Falwell five minutes to speak to the congregation. Falwell promised Jackson five minutes to speak to his congregation at TRBC the following Sunday.

According to Towns (personal communication, January 22, 2019), Falwell admitted that his beliefs had been wrong. He said, "I'm sorry—I was wrong. I was prejudiced. I'm a product of Campbell County here. I believed what I was always told, but I was wrong." Falwell then extended a scholarship to any person in the building who wanted to attend LU. Towns quoted Falwell as saying, "It's easy to say, 'I'm sorry,' but if you can say it with money, it means more." ${ }^{4}$ Additionally, in 1980, Falwell took Lynchburg African American civil rights advocate M.W. Thornhill, Jr., to lunch to apologize for his past actions, among other public apologies he gave (FitzGerald, 1981).

\section{Relationship between Race and Politics}

There appears to be a relationship between Falwell's beliefs about race and his political activism. His 1965 "Ministers and Marches" sermon was specifically critical of preachers who were involved in political matters like the civil rights movement. By 1979, Falwell had completely turned from his prior beliefs and helped found the Moral Majority in June 1979, which was, in his words, a "political movement" (Simon, 1999, p. 111). He was not the first preacher to make statements about political affairs; Billy Graham, had long expressed his political opinion, for example publically supporting Richard Nixon in his 1960, 1968, and 1972 presidential campaigns (FitzGerald, 1981).

\footnotetext{
${ }^{4}$ No one at Court Street Baptist Church could be reached to verify this account.
} 
He had also been outspoken about communism saying it was inspired "by the Devil himself” (Ray, 1985, p. 93). ${ }^{5}$

While it seems to have taken Falwell a long time to get involved in politics, he had really been involved all along. He may not have marched, but he did preach. Though many of his sermons from the 1950s and 1960s are either unavailable to the public or no longer exist in any recoverable manner, his "Segregation or Integration: Which?" and "Ministers and Marches" sermons are enough evidence for his political involvement. His messages on segregation and the civil rights movement were political statements in and of themselves, whether or not Falwell intended them to be. He had never been silent on political issues; he simply did not explicitly involve himself in political matters until later in his ministry.

Throughout the late 1960s and 1970s, Falwell stayed faithful to his fundamentalist beliefs that Christians are to be in the world but not of the world, and he slowly became more outspoken in the public arena on political matters, such as elections, congressional bills, and national defense policies. For example, in 1968, he invited George Wallace, a well-known segregationist who was running for president, to speak at TRBC. Senator Harry Byrd spoke at TRBC in 1970, and Falwell also hosted Georgia governor Lester Maddox on the Old Time Gospel Hour (Williams, 2010b). Falwell again supported Wallace in his 1982 bid for governorship by mailing letters to pastors in Alabama that Wallace agreed with the Moral Majority on several key issues ("The Rev. Jerry

\footnotetext{
${ }^{5}$ Graham eventually reversed his opinion on ministers making political statements, saying, "Evangelists can't be closely identified with any particular party or person." It is also worth noting that Graham made this statement after President Nixon's Watergate scandal (Ray, 1985, p. 93).
} 
Falwell...", 1982). During the 1976 presidential election, Falwell stated that "as a private citizen," he would vote for Gerald Ford (FitzGerald, 1981, para. 148). ${ }^{6}$ In 1979 he stated, "If you would like to know where I am politically, I am to the right of wherever you are. I thought Goldwater was too liberal!” (Ray, 1985, p. 10).

The political atmosphere of America in the mid-1970s made it possible to form an organization like the Moral Majority such as had not existed before. The civil rights movement had paved the way for grassroots activism and national, non-violent demonstrations. Additionally, there was a large population of generally religious, conservative citizens across the country who were not exceptionally politically active. Paul Weyrich, founder of the Heritage Foundation, anticipated this opportunity in the mid-1970s. He said, “The new political philosophy must be defined by us [conservatives] in moral terms, packaged in non-religious language, and propagated throughout the country by our new coalition. When political power is achieved, the moral majority will have the opportunity to recreate this great nation" (Balmer, 2014, para. 14).

Falwell said that his attitude toward ministers in politics changed because of issues such as abortion, school prayer, and pornography. He said that political issues were moral issues, adding, "I have to lend my weight where I have the biblical right to do so" (Ray, 1985, p. 28-29). In a 1979 sermon titled "America and Work," Falwell stated, “A long time ago I said I didn't want to get involved in [politics]; that's too volatile. And God has simply broken my heart over the fact that if I don't get involved in it I'm not going to have the right to stand behind this pulpit and preach much longer..." (Ray, 1985,

\footnotetext{
${ }^{6}$ Falwell's statement was made relatively soon after Jimmy Carter's Playboy interview.
} 
p. 5, 129). Former associates of Falwell say that his extensive travel schedule prompted the transition; he was told that he could reach a larger audience by talking about public policy matters than just speaking about theology (FitzGerald, 1981).

While Falwell did speak loudly about topics like abortion and homosexuality from the late 1970s through the end of his life, the civil rights movement in America is what changed his perspective regarding preachers in politics. The civil rights movement showed Falwell and many others how ministers could be politically active outside the pulpit. Preachers had long expressed their opinions on social issues such as drinking, presidential elections, and Supreme Court cases. The civil rights movement showed how ministers could advocate and demonstrate for change regarding national policy, not just transformation in the hearts of their congregation members.

\section{Tax-Exempt Status for Segregated Schools}

Part of the catalyst that spurned the creation of the Moral Majority and other conservative organizations was the Internal Revenue Service (IRS) revocation of taxexempt status for private schools and colleges that still maintained segregation policies. In May 1969, a group of African-American parents brought suit against the United States Treasury Department to prevent three all-white schools in Holmes County, Mississippi, from securing tax-exempt status. The case, Green v. Kennedy, was preliminarily decided in favor of the plaintiffs. That same year, President Richard Nixon ordered the IRS to deny tax-exempt status to "segregation academies" because the schools were not "charitable" educational organizations under Title VI of the 1964 Civil Rights Act. The ability to exempt "charitable" organizations, like some private schools, from income tax 
is found under section 501(c)(3) of the Internal Revenue Code. The case, now Green v. Connally, was upheld on appeal in U.S. District Court (Balmer, 2014, para. 11). Additionally, during President Jimmy Carter's administration, the IRS instituted new rules for private schools to prove that they did not have an "insignificant number of minority students," defined as "less than twenty percent of the minority school age population in the community served by the school" (Haberman, 2005, p. 239).

The ruling caught the attention of religious leaders, including Falwell. The 1964 Civil Rights Act changed the rules for how charitable organizations were eligible for taxexempt status. Bob Jones University received a letter regarding its status, and it defiantly said that it did not accept black students. BJU fought the IRS for several years, admitting one black worker and then married black students in 1975. In 1976, the IRS revoked the university's tax-exempt status. President Ronald Reagan's Treasury and Justice Departments reversed the IRS's revocations of BJU's tax-exempt status in 1982. After much public backlash, Reagan submitted legislation to Congress that would withhold taxexempt status for schools that still had segregation policies. This went against his campaign promises, treasured particularly by the Christian Right, that vowed to not intrude on the "biblically based policies of private institutions" (Haberman, 2005, p. 245). The government's move, in the words of BJU administrator Elmer L. Rumminger, "alerted the Christian school community about what could happen with government interference" in the affairs of religious institutions. He continued, "That was really the major issue that got us all involved" (Balmer, 2014, para. 21). 
In August 1977, the IRS proposed new rules for determining tax-exempt status primarily regarding schools that had been found in court to be racially discriminatory or were founded or substantially expanded during public school integration efforts. Schools with little or no minority enrollment would be given a "badge of doubt" by the IRS, and it would be on the school to prove that the their facilities and enrollment procedures were not discriminatory. A two-prong test would be used to determine discrimination: first, if the school enrolled a number of minority students equal to the minority population in the community, the school would be deemed nondiscriminatory. If the school could not meet this burden, it had to fulfill five other requirements to show it was exercising good-faith in enrolling minority students (Sulzberger, 1978).

LCA received a letter about its segregation policies from the IRS in 1978. The school had five black students out of 1,147 in its student body. Lynchburg's population at the time was 25 percent black (Williams, 2010b). For LCA to meet the IRS's proposed requirements, it would have had to enroll 286 minority students, obviously short of the IRS's proposed requirements. Several organizations were formed that fought the IRS's move, including Christian School Action (later the National Christian Action Coalition), of which Falwell was a member. Within weeks of publishing the proposed rules, at least half a million pieces of mail protesting the changes were mailed to the federal government. The IRS ultimately backed down from its plan (Martin, 1996).

While the IRS's crackdown on segregationist policies alerted evangelicals to increasing government intervention in religion-based education, issues like abortion and prayer in schools were the causes they publically rallied around to pull conservatives 
across the country together. Specifically, in the life of Falwell, the IRS's action likely helped spur his public involvement with politics. He said so himself in a 1980 interview with Eternity magazine, stating, "Back in the sixties I was criticizing pastors who were taking time out of their pulpits to involve themselves in the Civil Rights Movement or any other political venture. I said you're wasting your time from what you're called to do. Now I find myself doing the same thing and for the same reasons they did. Things began to happen." Falwell cited humanism in public schools and the Roe v. Wade Supreme Court decision and said, "Then adding to that the gradual regulation of various things it became very apparent the federal government would be harassing non-public schools, of which I have one of 16,000 right now" (Ray, 1985, p. 29).

\section{Conclusion}

Falwell's opinions on race issues evolved throughout his life. His early beliefs were influenced strongly by the environment he grew up in and also likely by the teachings he was exposed to at Baptist Bible College. He cited the civil rights movement, personal interactions, and the work of God in his life for his changed beliefs. He said that his personal relationship with Jesus Christ began the process of change in his heart; "at a point and time in my life I came to the place where I loved all persons in the same way

God loves all persons" (Simon, 1999, p. 151). Towns believed that the Great Commission changed Falwell's heart. However, according to pastors at TRBC, the church's outreach efforts toward the black population in Lynchburg did not change substantially (FitzGerald, 1981). 
Falwell believed secular humanism had its beginnings in the mindset of immoral communist leaders (Ray, 1985). In his early years, he saw integration and the civil rights movement as two avenues of bringing communism, and therefore secular humanism, into American society. He also believed that if the civil rights movement caused the country international embarrassment, it would be another way for communism to take hold in America (Williams, 2010a). Beginning in the 1970s and throughout the rest of his life, Falwell still fought against secular humanism making its way into American schools, public or private, and other spheres of life. He was a fierce anti-communist, once saying, “...register all communists? Not only should we register them...we should stamp it on their foreheads and send them back to Russia" (Ray, 1985, p. 34). However, in later years, Falwell no longer connected communism to race issues. Regarding preachers and politics, Falwell went from saying that preachers could not fulfill their duties if they were involved in politics to stating that they could not have the right to stand in the pulpit if they neglected to be involved in political matters. Of course, MLK and others had held this belief for years (King, 1968).

Falwell's interaction with race issues as well as politics and religion throughout his life were complex. Neither simple trust in human nature nor outright cynicism is appropriate in evaluating his evolving beliefs. A proper assessment must, in the words of God and Race in American Politics author Mark Noll (2008), "evoke both the goodness of the human creation and the persistence of evil in all branches of humanity" (p. 179). Falwell's fundamental conviction throughout his ministry - that Jesus is the only way to salvation and to know him is the highest good a person can attain - remains true. It is true 
that if each person on earth rightly followed that core truth, "a revival would grip our land such as we have never known before" (Thomas Road Baptist Church, 1965, p. 8). An equally true reality is that humans are imperfect creatures and will not completely get it right. People make secondary conclusions based on their fundamental beliefs. In the life of Jerry Falwell, Sr., he made some drastically different conclusions in 1958 than he did in 2007 while still maintaining his central conviction of salvation in Christ alone.

However, when a person is in a position of prominence like Falwell, the ramifications for his beliefs extend beyond his personal life. His opinions affect not only his family and congregation, but also the Lynchburg community and even the nation at large given his strong radio and television presence. Therefore, despite the enormous good that Falwell did in his life, his repentance from wrong beliefs, and the biblical teaching that consistently came from his pulpit, some may see a taint from his initial opinions and teachings on race on his early ministry, and by association, probably LCA and perhaps even LU. Others may rejoice for the sanctification that occurred in Falwell's life regarding his beliefs on race.

Falwell was not an avid advocate for civil rights in his later life, but he was not an outspoken segregationist as he once had been. It appears that his heart toward race issues had changed, but his priorities still remained set on issues such as abortion and homosexuality. Good men do not have to advocate for every good cause; indeed, there is not time enough to do every good thing under the sun. Matthew 6:21 says, "For where your treasure is, there your heart will be also" (English Standard Version). In other words, where one's treasure is, there his priorities will be also. 
EQUAL IN HIS SIGHT

\section{Disclaimer}

The Falwell family did not respond when asked to comment on the subject matter. 


\section{References}

Balmer, R. (2014). The real origins of the religious right. Politico Magazine. Retrieved from https://www.politico.com/magazine/story/2014/05/religious-right-realorigins $-107133 ? \mathrm{o}=2$.

Board members named for private school. (1966, December). The News.

Brooks, D. (1966, November). City churchmen planning independent day school. The Daily Advance, pp. 19, 33.

Daugherity, B. (2014). Desegregation in public schools. Encyclopedia Virginia. Retrieved from https://www.encyclopediavirginia.org/desegregation_in_public_schools\#start_ent ry.

Delaney, C. (2006). Columbus's ultimate goal: Jerusalem. Comparative Studies in Society and History, 48(2), 260-292. doi:http://dx.doi.org/10.1017/S0010417506000119.

Drake, W. (1979). Tax status of private segregated schools: The new revenue procedure. William \& Mary Law Review, 20(3), 463-512. Retrieved from https://heinonline.org/HOL/Page?collection=journals\&handle=hein.journals/wmlr 20\&id=475\&men_tab=srchresults.

Falwell, J. (1997). Falwell: An autobiography. Lynchburg, VA: Liberty House Publishers.

Falwell, J. (1987). Strength for the Journey: An Autobiography. New York, NY: Simon and Schuster. 
FitzGerald, F. (1981). A reporter at large: A disciplined, charging army. The New Yorker. Retrieved from https://www.newyorker.com/magazine/1981/05/18/a-disciplinedcharging-army.

Flint, G. (1978). Thomas Road Baptist Church: A study of the new fundamentalism (Doctoral dissertation). Retrieved from https://scholarworks.wm.edu/cgi/viewcontent.cgi?article=4043\&context=etd. Paper 1539625043.

Guggenheimer lifts ban on integration. (1966, November). The News.

Haberman, A. (2005). Into the wilderness: Ronald Reagan, Bob Jones University, and the political education of the Christian Right. The Historian, 67(2), 234-253. Retrieved from https://www.jstor.org/stable/24453232?seq=12\#metadata_info_tab_contents.

Harding, S. (2000). The book of Jerry Falwell: Fundamentalist language and politics. Princeton, NJ: Princeton University Press.

King, M. (1998). The autobiography of Martin Luther King, Jr. C. Carson (Ed). New York, NY: Warner Books, Inc.

Laurant, D. (2012). 50 years ago: Two students cross stubborn segregation line at E.C. Glass. The News \& Advance. Retrieved from https://www.newsadvance.com/news/local/years-ago-two-students-crossstubborn-segregation-line-at-e/article_420dc4b9-9114-5ba1-b9986e1403ab0abe.html.

Lavoie, J. (2013). Segregation and the Baptist Bible Fellowship: Integration, anti- 
communism, and religious fundamentalism, 1950-1970. Palo Alto, CA: Academica Press, LLC.

Lynchburg Christian Academy. (1967). Impact. [Pamphlet]. Lynchburg, VA: Author. Martin, W. (1996). With God on our side: The rise of the religious right in America. New York, NY: Broadway Books.

Menard, D. (2012). From vision to reality. Liberty Journal, Summer 2012. Retrieved from https://www.liberty.edu/journal/article/from-vision-to-reality/.

Noll, M. (2008). God and race in American politics: A short history. Princeton, NJ: Princeton University Press.

Ray, V. (1985). A rhetorical analysis of the political preaching of the Reverend Jerry Falwell: The Moral Majority sermons, 1979 (Electric Church, Demagogue) (Doctoral dissertation). Retrieved from LSU Historical Dissertations and Theses. "Redlining in Lynchburg: Bridges to progress." (2019). Retrieved from http://www.lynchburgva.gov/sites/default/files/COLFILES/City-CouncilManager/bridges_to_progress/documents/Bridges\%20July\%2025\%202019.pdf.

“Rev. Jerry Falwell, founder of the Moral Majority,...” (1982, September 27). United Press International. Retrieved from https://www.upi.com/Archives/1982/09/27/The-Rev-Jerry-Falwell-founder-ofthe-Moral-Majority/4409014919207/.

“Selma to Montgomery March.” (n.d.). Stanford University: The Martin Luther King, Jr. Research and Education Institute. Retrieved from https://kinginstitute.stanford.edu/encyclopedia/selma-montgomery-march. 
Simon, M. (1984). Jerry Falwell and the Jews. Middle Village, NY: Jonathan David Publishers, Inc.

Sulzberger, A. (1978, December 11). "Private academies protest tax plan.” The New York Times. Retrieved from https://www.nytimes.com/1978/12/11/archives/privateacademies-protest-tax-plan-hundreds-at-hearings-objectto.html?searchResultPosition=1.

Sutton, M. (2013). Jerry Falwell and the rise of the religious right: A brief history with documents. Boston, MA: Bedford/St. Martin's.

Teaching religion proposed. (1967, April). The News, pp. 1, 13.

Thomas Road Baptist Church. (1965). Ministers and marches. [Pamphlet]. Lynchburg, VA: Author.

Thomas, W. (2005). Virginia's "massive resistance" to school desegregation. Virginia Center for Digital History. Retrieved from http://www.vcdh.virginia.edu/solguide/VUS13/essay13a.html.

Williams, D. (2010a). God's own party: The making of the Christian right. New York, NY: Oxford University Press.

Williams, D. (2010b). Jerry Falwell's sunbelt politics: The regional origins of the Moral Majority. Journal of Policy History, 22(2), 125-147. Retrieved from https://search.proquest.com/docview/217015191?pq-origsite=summon.

Word of Life. (1958). Segregation or integration: Which? [Pamphlet]. Lynchburg, VA: Author. 